\title{
STABILITY ANALYSIS OF SOME SOYBEAN GENOTYPES USING PARAMETRIC AND NON PARAMETRIC METHODS IN MULTI- ENVIRONMENTS
}

\author{
Pinar CUBUKCU ${ }^{1}$, Mehmet KOCATURK ${ }^{2}$,Emre ILKER ${ }^{3}$, Abdullah KADIROGLU ${ }^{2}$, Yasemin \\ VURARAK ${ }^{1}$, Yesim SAHIN ${ }^{1}$, Mehmet KARAKUS $S^{4}$,Umran Akgun YILDIRIM ${ }^{4}$, Abdurrahim Tanju \\ GOKSOY ${ }^{5}$ Mehmet SINCIK ${ }^{5 *}$ \\ ${ }^{1}$ Eastern Mediterranean Agricultural Research Institute, Adana, TURKEY \\ ${ }^{2}$ Western Mediterranean Agricultural Research Institute, Antalya, TURKEY \\ ${ }^{3}$ Ege University, Faculty of Agriculture, Department of Field Crops, Izmir, TURKEY \\ ${ }^{4}$ South Eastern Anatolian Agricultural Research Institute, Sanliurfa, TURKEY \\ ${ }^{5}$ Bursa Uludag University, Faculty of Agriculture, Department of Field Crops, Bursa, TURKEY \\ *Corresponding author: sincik@uludag.edu.tr
}

Received: 06.12.2021

\begin{abstract}
Seed yields of 14 soybean genotypes were evaluated in four locations i.e. Adana, Şanlıurfa, Antalya and İzmir under second crop conditions through summer seasons from 2014 to 2016 . The study aims to estimate the stability parameters in terms of seed yield of 14 soybean genotypes by using different stability analysis methods across eleven environmental conditions and to study interrelationships among these stability methods. The analysis of variance for seed yield revealed that the genotypes and the environments as well as the genotype $x$ environment interactions (GEI) were statistically significant at $\mathbf{P}<\mathbf{0 . 0 1}$. Environmental effects were contributed $51.04 \%$ to the total sum of squares whereas GEI and genotype effects were $20.8 \%$ and $2.59 \%$, respectively. According to most stability methods, BATEM 223, BATEM 306, BATEM 317 and KASM 02 were determined to be stable genotypes. These genotypes demonstrated superior adaptability with high yield performances in many environments. Results of correlation analysis indicated that seed yield was positively and significantly correlated with $D_{i}{ }^{2}(P<0.01), S_{i}^{(6)}(P<0.05)$ and TOP $(P<0.01)$ and showed a negative and significant correlation with $P_{i}(P<0.01)$ and $R S(P<0.01)$. In addition, the coefficient of regression (bi) was positively significant associated with $\mathrm{CVi}$, ai $(\mathrm{P}<0.01)$ and $\mathrm{R}_{\mathrm{i}}^{2}(\mathrm{P}<0.05)$.
\end{abstract}

Keywords: Adaptation, Glycine max, genotype x environment interaction, stability, yield

\section{INTRODUCTION}

Soybean (Glycine max L.) is often called the miracle crop. It is the world's foremost provider of high-quality protein and edible oil for both human food and animal feed; in addition, it can improve soil fertility through its capability to fix atmospheric nitrogen (Morsy et al., 2015). Soybean consumption in Turkey has reached 1.8 million tons recently. However, only $9 \%$ of the consumption is met by local production (Yilmaz et al., 2018). Southeastern Anatolia is a region where agricultural production is common under second crop conditions. This region is one of the most important potential areas of Turkey to increase the very low soybean production (Kahraman et al., 2019). In general, the cultivation of second crop soybean in which winter cereals are the main crop means in late-planted soybean. Multilocation trials are needed to determine stable and high yielding genotypes as well as early genotypes suitable for the second crop conditions. Thus, it may be possible to make the right decision in terms of the stability and yield performance of the genotypes by taking advantage of the significant activity of the genotype $x$ environment interaction (GEI) in the second product conditions. In the GEI analysis, two terms "adaptability" and "stability" come to the fore. The terms adaptability and stability are related to the potential capacity of genotypes to positively assimilate environmental stimulus. Stability is considered as the capacity of genotypes to exhibit the most constant performance possible, as a function of environmental quality variations (Cruz et al., 2012; Ramalho et al., 2012). Stability and adaptability, and environmental stratification studies, although recognized as important, have been conducted in isolation and are, therefore, of little benefit for genetic improvement. Thus, the breeder needs to make decisions, based on at least two 
methodologies, one complementing the other (Cruz and Carneiro, 2006; Silveira et al., 2016).

An ideal variety is a genotype that has high mean yield and exhibits very little yield change in different environments. Therefore, stability analyses are important part of the breeding programs (Ilker et al., 2018). In this study, the adaptability and stability of soybean lines developed by the soybean breeding program were assessed using data from yield trials carried out in the different regions of Turkey under second crop conditions during 2014, 2015 and 2016 growing seasons. The main objectives of this study were: a) to analyze the influence of genotype, environment and GEI for seed yield; b) to evaluate the yield performance of soybean genotypes under favourable and unfavourable conditions; c) to most accurately determine the adaptation and stability performances of promising soybean genotypes using parametric and non-parametric stability methods; d) to estimate correlative relationships between stability parameters and average seed yield across all environments.

\section{MATERIALS AND METHODS}

Total 14 genotypes of which 10 were advanced soybean lines developed by the research institutes affiliated to the General Directorate of Agricultural Researches and Policies of Turkey and 4 were standard varieties were tested in the field experiments with replication performed during the three years $(2014,2015$ and 2016) in 4 locations (Adana, Sanliurfa, Antalya and Izmir) of second crop regions at the Mediterranean, Southeastern and Aegean Anatolia in Turkey. These genotypes were in third and fourth maturity groups (Table 1). The climate and soil characteristics of the places and years where the research was carried out, the amount of water given by irrigation and the average yields obtained are summarized in Table 2. As seen from this table, the climate characteristics varied based on the environments and Sanliurfa location is warmer and receives less precipitation compared to other locations. The experiments were conducted in a randomized complete block design with 4 replications. The sowings were done by using a plot drill at a 4-cm depth in the plots of $5 \mathrm{~m}$ in length consisting of 4 rows in each plot, in a distance of 70 $\mathrm{cm}$ and containing 45 plants in the $\mathrm{m}^{2}$. Sowings of the trials were generally completed from the second half of June until the beginning of July. The eighteen $\mathrm{kg} / \mathrm{da}$ DAP (Diammonium phosphate) was applied at the sowing time in the experiments. Before sowing, seeds were inoculated with Rhizobium bacteria culture according to Arioglu et al. (2012) where necessary. Weed control was done by hand or by the herbicide. Disease and pest control was performed at the required locations. In addition, sprinkler irrigation was done during the periods needed by plants in the experiments. The plots were harvested with a plot combine harvester when all the leaves on the plant fall and the pods turn yellow. A combined ANOVA was first performed to estimate the genotype $\mathrm{x}$ environment interaction. The Fprotected least significant difference (LSD) was calculated at the 0.05 probability level according to Steel and Torrie (1980).

Table 1. Code, pedigree, maturity group and breeding organization or variety owner of genotypes

\begin{tabular}{llcl}
\hline Code & Pedigree & $\begin{array}{c}\text { Maturity } \\
\text { group }\end{array}$ & $\begin{array}{c}\text { Breeding organization/ } \\
\text { variety owner }\end{array}$ \\
\hline BATEM 207 & \multicolumn{1}{c}{ Lines } & 3 & BATEM \\
BATEM 223 & Macon x Defiance & 3 & BATEM \\
BATEM 306 & Ataem 07 x Etae 08 & 4 & BATEM \\
BATEM 317 & J-357 x 9392 & 4 & BATEM \\
BDSA 05 & Sprite 87 x Apollo & 3 & BDUTAE \\
BDUS 04 & Umut 2002 x Sprite 87 & 3 & BDUTAE \\
KAMA & Macon x Apollo & 4 & KTAE \\
KANA & NE 3297 x AP 2292 & 4 & KTAE \\
KASM 02 & Sprite 87 x Macon & 3 & KTAE \\
KASM 03 & Sprite 87 x Macon & 3 & KTAE \\
\hline ARISOY & \multicolumn{1}{c}{ Standards } & & Cukurova University \\
ATAEM 07 & & 3 & BATEM \\
BRAVO & & 4 & PROGEN Seed Co. \\
NOVA & & 3 & MAY Agro Co. \\
\hline
\end{tabular}


Table 2. Data experiment, soil properties and climate for environments where the experiments were conducted

\begin{tabular}{|c|c|c|c|c|c|c|c|}
\hline Code & $\begin{array}{c}\text { Growing } \\
\text { seasons }\end{array}$ & Environments & $\begin{array}{c}\text { Soil } \\
\text { properties }\end{array}$ & $\begin{array}{c}\text { Mean } \\
\text { temperatures } \\
\text { growing season } \\
\left({ }^{\circ} \mathrm{C}\right)\end{array}$ & $\begin{array}{c}\text { Rain-fall } \\
(\mathrm{mm})\end{array}$ & $\begin{array}{l}\text { Irrigation } \\
(\mathrm{mm})\end{array}$ & $\begin{array}{l}\text { Mean } \\
\text { Yield } \\
\left(\mathrm{t} \mathrm{ha}^{-1}\right)\end{array}$ \\
\hline E1 & 2014 & Adana & $\mathrm{pH}=7.5$, clay-loam & 24.0 & 239.1 & 460 & 3.32 \\
\hline E2 & 2015 & Adana & $\mathrm{pH}=7.5$, clay-loam & 24.1 & 194.2 & 505 & 3.95 \\
\hline E3 & 2014 & Sanliurfa & $\mathrm{pH}=7.8$, sandy clay & 26.0 & 116.2 & 633 & 4.15 \\
\hline E4 & 2015 & Sanliurfa & $\mathrm{pH}=7.8$, sandy clay & 26.1 & 94.4 & 655 & 3.93 \\
\hline E5 & 2016 & Sanliurfa & $\mathrm{pH}=7.8$, sandy clay & 26.9 & 57.8 & 692 & 3.16 \\
\hline E6 & 2014 & Antalya & $\mathrm{pH}=8.6$, clay-silt & 23.8 & 302.3 & 347 & 2.63 \\
\hline E7 & 2015 & Antalya & $\mathrm{pH}=8.5$, clay-silt & 23.7 & 197.9 & 452 & 3.07 \\
\hline E8 & 2016 & Antalya & $\mathrm{pH}=8.6$, clay-silt & 24.5 & 97.3 & 553 & 3.61 \\
\hline E9 & 2014 & Izmir & $\mathrm{pH}=7.4$, clay-silt & 23.3 & 241.5 & 408 & 3.68 \\
\hline E10 & 2015 & Izmir & $\mathrm{pH}=7.4$, clay-silt & 23.7 & 210.3 & 440 & 3.49 \\
\hline E11 & 2016 & Izmir & $\mathrm{pH}=7.5$, clay-silt & 24.5 & 61.7 & 588 & 3.09 \\
\hline
\end{tabular}

To present the methods of stability analysis, a two-way linear model is assumed for convenience as follows:

$$
X_{i j}=\mu+e_{j}+g_{i}+(g e)_{i j}+\varepsilon_{i j}
$$

where $X_{i j}$ is the observed phenotypic mean value of genotype $\mathrm{i}(\mathrm{i}=1, \ldots, \mathrm{G})$ in environment $\mathrm{j}(\mathrm{j}=1, \ldots, \mathrm{E})$, and $\mu, e_{j}, g_{i},(g e)_{i j}$, and $\varepsilon_{i j}$, represent the overall population mean, the effect of the $j$-th environment, the effect of the $i$ th genotype, the effect of the interaction between the i-th genotype and the $\mathrm{j}$-th environment and the mean random error of the $\mathrm{i}$-th genotype in the $\mathrm{j}$-th environment, respectively, with $\mathrm{Xi}$., $\mathrm{X} . \mathrm{j}$ and $\mathrm{X}$.. denoting the marginal means of genotype $i$, environment $j$ and the overall mean, respectively (Becker and Leon, 1988). Then seventeen parametric stability parameters were studied by Eberhart and Russel's (1966) regression coefficient $\left(b_{i}\right)$, Pinthus's (1973) coefficients of determination $\left(\mathrm{R}_{\mathrm{i}}^{2}\right)$, Wricke's (1962) ecovalance $\left(\mathrm{W}_{\mathrm{i}}{ }^{2}\right)$, Shukla's $(1972)$ stability variance $\left(\sigma_{\mathrm{i}}{ }^{2}\right)$, Francis and Kannenberg's (1978) coefficient of variability $\left(\mathrm{CV}_{\mathrm{i}}\right)$ and environmental variance $\left(\mathrm{S}_{\mathrm{i}}{ }^{2}\right)$, Tai's (1971) environmental effects $\left(\alpha_{i}\right)$ and deviation from the linear response $\left(\lambda_{\mathrm{i}}\right)$, Plaisted and Peterson's (1959) mean variance component for pair-wise GEI (P59), Hernandez et al. (1993)'s desirability index $\left(\mathrm{D}_{\mathrm{i}}{ }^{2}\right)$, and Lin and Binn's (1988) superiority index $\left(\mathrm{P}_{\mathrm{i}}\right)$. These parametic models have been adopted and used by many researchers in previous studies.

The nonparametric stability measures were developed more recently. In this study, several non-parametric statistics were also used to estimate the stability. These statistics consisted of three nonparametric stability statistics $\left(\mathrm{Si}^{(2)}, \mathrm{Si}^{(3)}\right.$ and $\mathrm{Si}^{(6)}$ ) (Huehn, 1979; Nassar and Huehn, 1987). In addition, the other two nonparametric statistics were used. One of them is a method described by Fox et al. (1990) who proposed a non-parametric superiority method for general adaptability using a stratified ranking of cultivars. Kang's (1988) rank-sum (RS) is another non-parametric stability procedure where both yield and Shukla's (1972) stability variance were used as selection criteria. In addition, Spearman's rank correlation coefficients between yields and stability parametric and non-parametric methods for 14 soybean genotypes across 11 environments were determined by correlation analysis. All statistical analyses were performed using the SAS (Statistical Analyses Systems) program (SAS Institute, 1999).

\section{RESULTS AND DISCUSSIONS}

Results of combined variance analysis for seed yield of 14 soybean genotypes examined under second crop conditions in the eleven environments are presented in Table 3. The result of variance analysis revealed that the effects of genotypes and the environments as well as the GEI on seed yield were statistically significant at $\mathrm{P}<0.01$ (Table 3). Environmental effects were contributed $51.0 \%$ to the total sum of squares whereas GEI and genotype effects were $20.8 \%$ and $2.59 \%$, respectively (Table 3 ). The large environmental sum of squares indicated that there were large differences among the environments for average seed yields. The GEI sum of squares is about 8 times larger than the genotype sum of squares. This result suggested that the genotypes had different responses across environments in terms of seed yield. As partly different from our findings, Morsy et al. (2015) found that $61.8 \%$ of the total sum of squares was attributed to GEI whereas the contribution of environment and genotype to total variation were $12.0 \%$ and $11.5 \%$, respectively. They reported that there were substantial differences in genotypic response across environments which advocated the adequacy of running stability analysis. 
Table 3. Results of analysis of variance for seed yield from trials conducted with 14 soybean genotypes in 11 environments under second crop conditions.

\begin{tabular}{lrrrrrr}
\hline Source & \multicolumn{1}{c}{ df } & \multicolumn{1}{c}{ SS } & \multicolumn{1}{c}{ MS } & F Ratio & Prob>F & $\%$ Total SS \\
\hline Model & 186 & 1787434.3 & 9609.8 & 8.1822 & $<0.001$ \\
Environment (E) & 10 & 1169482.0 & $116948.0^{* *}$ & 47.5778 & $<0.001$ & 51.04 \\
Replication [Environment]\&Random & 33 & 81115.4 & $2458.0^{* *}$ & 2.0929 & 0.0005 & 3.54 \\
Genotype (G) & 13 & 59312.9 & $4562.5^{* *}$ & 3.8847 & $<0.001$ & 2.59 \\
G E E & 130 & 477524.0 & $3673.3^{* *}$ & 3.1276 & $<0.001$ & 20.84 \\
Pooled Error & 429 & 503852.9 & 1174.5 & & & \\
Corrected Total & 615 & 2291287.2 & & & $\mathrm{R}^{2}: 0.78$ \\
\hline
\end{tabular}

The coefficient of variation (CV) determined as $9.89 \%$ in the combined variance analysis for seed yield. Carvalho et al. (2002) reported that a maximum variation coefficient of $16.0 \%$ can be proposed for seed yield under field conditions. Our findings on the coefficient of variation correspond to that of Cucolotto et al. (2007). In our study, a relatively low coefficient of variation demonstrated the existence of good experimental precision. The estimated coefficient of determination $\left(\mathrm{R}^{2}\right)$ revealed that $78.0 \%$ of the general variation for seed yield was derived from the GEI model. Environments over genotypes gave seed yields ranging from $2.63 \mathrm{t} \mathrm{ha}^{-1}$ for E6 to $4.15 \mathrm{t} \mathrm{ha}^{-1}$ for E3. Mean seed yield of genotypes over environments ranged from $3.27 \mathrm{t} \mathrm{ha}^{-1}$ for ATAEM 07 to $3.63 \mathrm{t} \mathrm{ha}^{-1}$ for BATEM 223. Generally, all the genotypes except for BATEM 207, KANA and standard cultivars had high seed yields. However, genotypes showed large differences across the environments in terms of seed yield (Table 4). Our findings were consistent with the results reported by Gurmu et al. (2009), Chaudhary and Wu (2012), Sousa et al. (2015), Edugbo et al. (2015), Cheelo et al. (2017).

\section{Parametric Stability Components}

The results of eleven parametric stability parameters and mean seed yields for 14 soybean genotypes at the 11 environments are presented in Table 5. According to Eberhart and Russell (1966), regression coefficients (bi) approximating 1.0 coupled with deviation from regression $\left(\mathrm{S}_{\mathrm{di}}^{2}\right)$ of zero indicate average stability. For Eberhart and Russell (1966) the ideal genotype has a high average yield, regression coefficient equal to the unit $(b=1)$, and deviation regression the lowest possible. If the regression coefficient (b value) is not significantly different from unity, the genotype is considered adapted to all environments. Also, the genotype that has a significant $b$ value greater than one is more responsive to high yielding environments, whereas any genotype with significant $b$ value less than one is adapted to low yielding environments (Morsy et al., 2015).

Genotypes BDSA 05, BDUS 04 and KAMA gave values of regression coefficient above 1.0 and medium or higher seed yield, whereas BATEM 207 had medium level seed yield and a regression coefficient lower than 1 . Therefore, genotypes BDSA 05, BDUS 04 and KAMA would be suggested for cultivation under favourable conditions, while BATEM 207 were moderately adapted across unfavourable environment conditions. The genotypes BATEM 223, BATEM 306 and BATEM 317 were well adapted to all environments due to their higher seed yields than average and regression coefficients near to 1.0 for seed yield. Therefore, these genotypes were considered stable in response to all environments according to Eberhard and Russell (1966). Also, genotypes KASM 02, KASM 03 and KANA having seed yields near to average yield and regression coefficients near to 1.0 were moderately adapted to all environments, whereas standard cultivars (ARISOY, ATAEM 07, BRAVO and NOVA) having lower seed yields than average and regression coefficients near to 1.0 were poorly adapted to all environments. Our findings correspond to that of Tadesse et al. (1997), Carvalho et al. (2002), Hossain et al. (2003), Oliveira et al. (2012), El-Refaey et al. (2013) and Morsy et al. (2015), who reported that some cultivars had high yields under favourable environments, while others adapted to poor environments. In addition, the current results are supported the conclusion of Yothasiri and Somwang (2000), Primomo et al. (2002) and Olievira et al. (2012) who reported that genotypes with higher stability or good adaptability in a wide range of environment were found for seed yield.

The coefficient of determination $\left(R^{2}\right)$, which is the predictability of response estimates $\left(R_{i}^{2}=1\right)$, ranged from 0.55 to 0.92 . It defines the amount of contribution proportionally of the stability model containing the genotype, environment and GEI effects on the general variation in terms of seed yield. None of the values of coefficient of determinations examined was significantly different from 1.0. Pinthus (1973) used the coefficient of determination as a stability parameter and assumed that the genotypes having the coefficient of determination near to 1 were stable. In general, stability states of the genotypes determined according to Eberhart and Russell's (1966) regression coefficients (bi), with some exceptions were verified by Pinthus's (1973) coefficient of determination $\left(\mathrm{R}_{\mathrm{i}}^{2}\right)$ too. Low values of the coefficient of determination $\left(\mathrm{R}^{2}\right)$ indicate high dispersion of the data and therefore low reliability in the type of environmental response determined by the regression analysis (Freiria et al., 2018). Cruz (2006) found that the coefficients of determination were lower than $70 \%$, in which this percentage is a reference for the regression to satisfactorily explain the behavior of the genotype according to the environment. 
Table 4. Average seed yields of soybean genotypes tested in eleven environments $\left(t \mathrm{th}^{-1}\right)$

\begin{tabular}{|c|c|c|c|c|c|c|c|c|c|c|c|c|}
\hline Genotypes & $* \mathrm{E} 1$ & E2 & E3 & E4 & E5 & E6 & E7 & E8 & E9 & E10 & E11 & Mean \\
\hline BATEM 207 & $3.57 \mathrm{a}-\mathrm{d}$ & 3.40 & 3.91.de & $3.83 \mathrm{c}-\mathrm{e}$ & 3.13 & $2.70 \mathrm{~b}-\mathrm{c}$ & $3.28 \mathrm{a}-\mathrm{d}$ & $3.55 \mathrm{~b}-\mathrm{d}$ & $3.66 \mathrm{a}-\mathrm{d}$ & $3.63 b-d$ & $3.46 \mathrm{a}$ & $3.47 \mathrm{~b}-\mathrm{d}$ \\
\hline BATEM 223 & $3.70 a-b$ & 4.41 & $4.21 \mathrm{a}-\mathrm{d}$ & $3.64 \mathrm{~d}-\mathrm{f}$ & 2.92 & $3.19 \mathrm{a}$ & $3.32 \mathrm{a}-\mathrm{c}$ & $3.71 \mathrm{a}-\mathrm{d}$ & $3.83 \mathrm{a}-\mathrm{d}$ & $3.62 \mathrm{~b}-\mathrm{d}$ & $3.41 \mathrm{a}$ & $3.63 \mathrm{a}$ \\
\hline BATEM 306 & $3.46 \mathrm{a}-\mathrm{d}$ & 3.69 & $3.91 \mathrm{de}$ & $3.99 \mathrm{~b}-\mathrm{d}$ & 3.16 & $2.57 \mathrm{c}-\mathrm{d}$ & $3.35 \mathrm{a}-\mathrm{c}$ & $3.70 \mathrm{a}-\mathrm{d}$ & $3.88 \mathrm{a}-\mathrm{c}$ & $3.65 \mathrm{bc}$ & $3.35 \mathrm{ab}$ & $3.55 \mathrm{ab}$ \\
\hline BATEM 317 & $2.81 \mathrm{e}$ & 4.14 & $4.20 \mathrm{~b}-\mathrm{d}$ & $4.23 \mathrm{~b}$ & 3.24 & $2.77 \mathrm{a}-\mathrm{c}$ & $3.38 \mathrm{a}-\mathrm{b}$ & $3.22 \mathrm{~d}$ & $4.03 \mathrm{ab}$ & $3.89 \mathrm{ab}$ & $3.04 \mathrm{~b}-\mathrm{e}$ & $3.54 \mathrm{ab}$ \\
\hline BDSA 05 & $3.67 \mathrm{a}-\mathrm{b}$ & 3.99 & $4.47 \mathrm{a}-\mathrm{c}$ & $4.15 \mathrm{bc}$ & 3.15 & $2.19 \mathrm{~d}-\mathrm{e}$ & $3.28 \mathrm{a}-\mathrm{d}$ & $3.84 \mathrm{a}-\mathrm{c}$ & $3.47 \mathrm{~b}-\mathrm{e}$ & $3.35 \mathrm{c}-\mathrm{f}$ & $2.91 \mathrm{~d}-\mathrm{f}$ & $3.50 \mathrm{a}-\mathrm{c}$ \\
\hline BDUS 04 & $3.79 \mathrm{a}$ & 3.86 & $4.59 a b$ & $4.70 \mathrm{a}$ & 3.53 & $2.47 \mathrm{c}-\mathrm{d}$ & $2.96 \mathrm{~b}-\mathrm{f}$ & $4.17 \mathrm{a}$ & $3.02 \mathrm{e}$ & 3.27 ef & $2.66 \mathrm{fg}$ & $3.55 \mathrm{ab}$ \\
\hline KAMA & $3.44 \mathrm{a}-\mathrm{d}$ & 3.82 & $4.71 \mathrm{a}$ & $4.35 \mathrm{ab}$ & 3.49 & $2.02 \mathrm{e}$ & $2.77 \mathrm{~d}-\mathrm{f}$ & $3.45 \mathrm{c}-\mathrm{d}$ & $3.77 \mathrm{a}-\mathrm{d}$ & $3.67 \mathrm{a}-\mathrm{c}$ & $2.98 \mathrm{c}-\mathrm{f}$ & $3.50 \mathrm{a}-\mathrm{c}$ \\
\hline KANA & $2.98 \mathrm{~d}-\mathrm{e}$ & 3.64 & $4.50 \mathrm{a}-\mathrm{c}$ & $4.07 \mathrm{bc}$ & 2.99 & $2.60 \mathrm{c}-\mathrm{d}$ & $2.71 \mathrm{f}$ & $3.52 \mathrm{c}-\mathrm{d}$ & $3.56 \mathrm{~b}-\mathrm{e}$ & $3.99 \mathrm{a}$ & $3.25 \mathrm{a}-\mathrm{c}$ & $3.44 \mathrm{~b}-\mathrm{e}$ \\
\hline KASM 02 & $3.13 \mathrm{~b}-\mathrm{e}$ & 3.78 & $4.14 b-d$ & $3.82 \mathrm{c}-\mathrm{e}$ & 3.15 & $2.65 b-c$ & $2.72 \mathrm{f}$ & $4.09 a-b$ & $3.83 \mathrm{a}-\mathrm{d}$ & $3.62 \mathrm{~b}-\mathrm{d}$ & $3.52 \mathrm{a}$ & $3.50 \mathrm{a}-\mathrm{c}$ \\
\hline KASM 03 & $3.04 \mathrm{c}-\mathrm{e}$ & 4.08 & $4.06 \mathrm{~cd}$ & $4.06 \mathrm{bc}$ & 3.14 & $3.04 a-b$ & $2.75 \mathrm{e}-\mathrm{f}$ & $3.40 \mathrm{c}-\mathrm{d}$ & $4.17 \mathrm{a}$ & $3.58 \mathrm{~b}-\mathrm{e}$ & $3.23 \mathrm{a}-\mathrm{d}$ & $3.50 \mathrm{a}-\mathrm{c}$ \\
\hline ARISOY & $3.62 \mathrm{a}-\mathrm{c}$ & 4.17 & $4.15 \mathrm{~b}-\mathrm{d}$ & $3.66 \mathrm{~d}-\mathrm{f}$ & 3.24 & $2.56 \mathrm{c}-\mathrm{d}$ & $2.85 \mathrm{c}-\mathrm{f}$ & $3.28 \mathrm{~d}$ & $3.27 \mathrm{de}$ & $3.54 \mathrm{c}-\mathrm{e}$ & $2.97 \mathrm{c}-\mathrm{f}$ & $3.40 \mathrm{c}-\mathrm{f}$ \\
\hline ATAEM 07 & $3.20 \mathrm{a}-\mathrm{e}$ & 3.72 & $3.79 \mathrm{de}$ & 3.45 ef & 2.88 & $2.57 \mathrm{c}-\mathrm{d}$ & $3.64 \mathrm{a}$ & $3.65 \mathrm{a}-\mathrm{d}$ & $3.35 \mathrm{c}-\mathrm{e}$ & $3.31 \mathrm{~d}-\mathrm{f}$ & $2.42 \mathrm{~g}$ & $3.27 \mathrm{f}$ \\
\hline BRAVO & $2.80 \mathrm{e}$ & 3.94 & $3.87 \mathrm{de}$ & 3.59 ef & 3.15 & $2.87 \mathrm{a}-\mathrm{c}$ & 3.24 a-e & $3.45 \mathrm{c}-\mathrm{d}$ & $3.84 \mathrm{a}-\mathrm{d}$ & $3.13 \mathrm{f}$ & $2.85 \mathrm{ef}$ & $3.34 \mathrm{~d}-\mathrm{f}$ \\
\hline NOVA & $3.17 \mathrm{~b}-\mathrm{e}$ & 4.33 & $3.55 \mathrm{e}$ & $3.44 \mathrm{f}$ & 3.07 & $2.59 \mathrm{c}-\mathrm{d}$ & $2.79 \mathrm{~d}-\mathrm{f}$ & $3.56 \mathrm{~b}-\mathrm{d}$ & $3.94 \mathrm{ab}$ & $2.73 \mathrm{~g}$ & $3.28 \mathrm{a}-\mathrm{c}$ & 3.31 ef \\
\hline Mean & $3.32 \mathrm{DE}$ & $3.95 \mathrm{~B}$ & $4.15 \mathrm{~A}$ & $3.93 \mathrm{~B}$ & $3.16 \mathrm{EF}$ & $2.63 \mathrm{G}$ & $3.07 \mathrm{~F}$ & $3.61 \mathrm{C}$ & $3.68 \mathrm{C}$ & $3.49 \mathrm{CD}$ & $3.09 \mathrm{~F}$ & \\
\hline
\end{tabular}

Table 5. Mean seed yield values $\left(\mathrm{t} \mathrm{ha}^{-1}\right)$ and 17 stability parameters of 14 soybean genotypes at the 11 environments in the second crop conditions

\begin{tabular}{|c|c|c|c|c|c|c|c|c|c|c|c|c|c|c|c|c|c|}
\hline \multirow{2}{*}{ Genotype } & \multicolumn{17}{|c|}{ Stability parameters } \\
\hline & $\mathrm{X}$ & $\mathrm{b} i$ & $\mathrm{R}_{\mathrm{i}}{ }^{2}$ & $\mathrm{~W}_{\mathrm{i}}^{2}$ & $\mathrm{Si}^{2}$ & $\mathrm{CV}_{i}$ & $\sigma_{i}^{2}$ & P59 & $\mathrm{Di}^{2}$ & $\alpha_{i}$ & $\lambda i$ & $\mathrm{P} i$ & $\mathrm{~S}_{i}(2)$ & $\mathrm{S}_{i}(3)$ & $S_{i}(6)$ & TOP & RS \\
\hline ARISOY & 3.39 & 0.92 & 0.81 & 5259.3 & 2541.3 & 14.8 & 537.0 & 742.3 & 331.7 & -0.02 & 1.92 & 2132.1 & 16.1 & 16.1 & 3.93 & 27.3 & 13 \\
\hline ATAEM 07 & 3.27 & 0.80 & 0.58 & 10236.5 & 2149.2 & 14.1 & 1117.7 & 1010.3 & 321.1 & -0.23 & 3.34 & 3032.6 & 16.6 & 15.3 & 3.17 & 9.1 & 25 \\
\hline BATEM 207 & 3.46 & 0.67 & 0.73 & 6257.6 & 1156.4 & 9.8 & 653.5 & 796.1 & 341.8 & -0.38 & 1.20 & 1712.2 & 13.0 & 15.5 & 4.00 & 9.1 & 13 \\
\hline BATEM 223 & 3.63 & 0.74 & 0.68 & 7049.5 & 1850.6 & 11.8 & 745.9 & 838.7 & 357.4 & -0.23 & 2.18 & 1060.2 & 16.9 & 29.2 & 6.28 & 54.5 & 9 \\
\hline BATEM 306 & 3.55 & 0.95 & 0.92 & 2202.3 & 1831.2 & 12.0 & 180.4 & 577.7 & 347.9 & -0.11 & 0.70 & 1123.2 & 7.7 & 8.5 & 3.40 & 36.3 & 4 \\
\hline BATEM 317 & 3.54 & 1.07 & 0.73 & 8729.7 & 3231.6 & 16.0 & 941.9 & 929.2 & 346.0 & 0.06 & 3.17 & 1360.5 & 17.8 & 32.7 & 6.55 & 63.6 & 14 \\
\hline BDSA 05 & 3.49 & 1.26 & 0.89 & 6605.9 & 4020.2 & 18.1 & 694.2 & 814.8 & 339.9 & 0.31 & 1.70 & 1450.9 & 14.2 & 18.8 & 4.94 & 36.3 & 13 \\
\hline BDUS 04 & 3.54 & 1.23 & 0.68 & 21180.8 & 5605.0 & 21.1 & 2394.6 & 1599.7 & 344.5 & 0.34 & 6.90 & 1760.1 & 33.0 & 45.8 & 8.21 & 45.4 & 16 \\
\hline BRAVO & 3.33 & 0.75 & 0.71 & 6189.7 & 1810.4 & 12.7 & 645.6 & 792.4 & 327.9 & -0.22 & 1.90 & 2438.1 & 16.5 & 13.8 & 3.65 & 9.1 & 15 \\
\hline KAMA & 3.50 & 1.48 & 0.89 & 11559.4 & 5381.3 & 20.9 & 1272.1 & 1081.6 & 338.3 & 0.52 & 2.19 & 1708.8 & 22.0 & 27.1 & 5.71 & 36.3 & 18 \\
\hline KANA & 3.44 & 1.20 & 0.79 & 8010.2 & 3561.4 & 17.3 & 858.0 & 890.5 & 334.9 & 0.16 & 2.73 & 1838.5 & 19.1 & 22.0 & 4.74 & 18.2 & 19 \\
\hline KASM 02 & 3.49 & 1.08 & 0.81 & 6287.7 & 2654.1 & 14.7 & 657.0 & 797.7 & 341.9 & -0.01 & 2.30 & 1579.9 & 15.5 & 17.4 & 4.02 & 18.2 & 13 \\
\hline KASM 03 & 3.50 & 0.97 & 0.74 & 6728.3 & 2598.8 & 14.5 & 708.4 & 821.4 & 343.1 & -0.04 & 2.45 & 1505.4 & 15.5 & 18.6 & 4.36 & 18.2 & 12 \\
\hline NOVA & 3.31 & 0.82 & 0.55 & 13084.1 & 2783.3 & 15.9 & 1449.9 & 1163.7 & 324.9 & -0.15 & 4.63 & 3047.2 & 22.7 & 21.0 & 4.33 & 18.2 & 26 \\
\hline
\end{tabular}


In a previous study, it was repoted that some genotypes were adapted to favourable environments since values of coefficient of regression were greater than the unit $(b>1)$, and the coefficient of determination higher than $70 \%$ (Oleivera et al., 2012).

Wricke (1962) suggested the use of ecovalance $\left(\mathrm{W}_{\mathrm{i}}{ }^{2}\right)$ as a stability parameter. Ecovalence measures the contribution of a genotype to the GEI. The genotypes with the lowest ecovalence $\left(\mathrm{W}_{\mathrm{i}}^{2}\right)$ has fewer fluctuations across the environments and therefore it is considered to be more stable than others (Wricke, 1962). Genotypes ARISOY, BATEM 207, BATEM 306, BDSA 05, BRAVO and KASM 02 were regarded as stable due to their the lowest ecovalance $\left(\mathrm{W}_{\mathrm{i}}{ }^{2}\right)$ values. The unstable genotypes were BDUS 04, NOVA, KAMA and ATAEM 07 having the highest stability ecovalence values. This result shows that the unstable genotypes contribute the highest amount of variation to the total GEI variance and this leads the genotype unstable. Our results on ecovalence values of genotypes were similar to those found by Yue et al. (1997) and Freiria et al. (2018). The genotypes BATEM 207, BATEM 223, BATEM 306 and BRAVO with the lowest environmental variance $\left(\mathrm{S}_{\mathrm{i}}^{2}\right)$ values were considered relatively more stable than other genotypes. The same genotypes had the lowest coefficient of variation $\left(\mathrm{CV}_{\mathrm{i}}\right)$ values. According to Francis and Kannenberg (1978), genotypes exhibiting low environmental variance $\left(\mathrm{S}_{\mathrm{i}}{ }^{2}\right)$ and coefficient of variation $\left(\mathrm{CV}_{\mathrm{i}}\right)$ are considered stable (Lin et al., 1986). Therefore, BATEM 207, BATEM 223, BATEM 306 and BRAVO genotypes having both lower environmental variance $\left(\mathrm{S}_{\mathrm{i}}^{2}\right)$ and lower coefficient of variation $\left(\mathrm{CV}_{\mathrm{i}}\right)$ values could be considered as stable.

The stability method of Shukla (1972) was used as a stability parameter in the current study. Shukla (1972) proposed the stability variance $\left(\sigma_{i}^{2}\right)$, the amount of genotype by environment variance associated with genotypes. In the current study, the genotypes BATEM 306, ARISOY, BATEM 207, BRAVO, KASM 02 and BDSA 05 had the lowest stability variance $\left(\sigma_{i}^{2}\right)$ whereas genotypes NOVA, KAMA and ATAEM 07 had the highest values. No one of the genotypes had statistically significant stability variance $\left(\sigma_{\mathrm{i}}^{2}\right)$. Nevertheless, the genotypes BATEM 306, ARISOY, BATEM 207, BRAVO, KASM 02 and BDSA 05 could be considered as stable while genotypes NOVA, KAMA and ATAEM 07 as unstable. This stability variance is a linear function of Wricke's ecovalence (Wricke and Weber, 1980; Kang et al., 1987). However, Shukla's model differs in the ranking of the genotypes from Wricke (1962) when covariates (locations means) were considered. Contrary to our findings, Morsy et al. (2015) noted that concerning the stability-variance method of Shukla (1972), that no one of the tested genotypes were to be stable because they had highly significant $\sigma^{2}$ values. The same researchers explained that although the 12 genotypes had highly significant values of $\sigma^{2}$ (unstable based on Shukla model), they were stable considering yield stability statistic due to their high yields.
When a genotype has small values in terms of meanvariance component for a pair-wise genotype-environment interaction (P59), it can be considered to be a stable genotype (Plaisted and Peterson,1959). Thus, the stability parameter, P59 of Plaisted and Peterson (1959) revealed that the genotypes BATEM 306, ARISOY, BRAVO, KASM 02, BATEM 207 had lower P59 values and could be considered as stable genotypes. However, the genotypes BDUS 04, NOVA, KAMA and ATAEM 07 with the highest P59 values were determined to be unstable. Hernandez et al. (1993) desirability index $\left(\mathrm{D}_{\mathrm{i}}^{2}\right)$ ranged between 321.1 and 347.9 according to the current genotypes. According to the significance tests, there were no significant differences between the $\mathrm{D}_{\mathrm{i}}^{2}$ of the genotypes. Considering the desirability index of Hernandez et al. (1993), it can be assumed that all genotypes are stable.

In the current study, two stability method proposed by Tai (1971) were also examined as stability parameters. The first of these was $\alpha$ that measure the linear response of environmental effects while the second one is $\lambda$ that reflects the deviation from a linear response in terms of the magnitude of the error variance. The perfect stable genotype will not change its performance from one environment to another according to Tai (1971). This is equivalent to state $\alpha=-1$ and $\lambda=1$. However, the perfect stable genotypes rarely exist, so the plant breeder will have to be satisfied with a statistically admissible level of stability. The values $(\alpha=0$ and $\lambda=1)$ will be referred to as average stability, whereas the values $(\alpha>0$ and $\lambda=1)$ will be as below average stability, and the values $(\alpha<0$ and $\lambda=$ -1) will be referred to as above-average stability (Morsy et al., 2015). In our study, all of the genotypes could be considered as genotypes having average stability since they were the values close to $\alpha=0$ and $\lambda=1$. None of the genotypes showed statistical values above or below average stability. In a similar study, Morsy et al. (2015) reported that 17 soybean genotypes out of 26 were spotted in the average stability area (at $\mathrm{P}=0.99$ ) while only one genotype (H4L24) had degree of low average stability. Similar results were obtained by Al-Assily et al. (1996) and Morsy et al. (2012).

Considering the superiority index $(\mathrm{Pi})$ value of Lin and Binns (1988), a genotype with the lowest superiority index (Pi) value should be regarded as a superior genotype. Consequently, the genotypes BATEM 223 and BATEM 306 having the lowest superiority index $(\mathrm{Pi})$ values and the highest average seed yields were found to be superior genotypes. According to Lin and Binns (1988) theory, two of these genotypes could be considered stable. In a similar study, Oliveira et al. (2012) reported that the cultivars MSOY 7908 RR, M-SOY 8199 RR, BRS VALIOSA RR and M-SOY 7578 RR showed general adaptation because they had higher average grain yield and lower values of the Pi general parameter. They explained that this result indicates that these genotypes can maintain acceptable performance, even under unfavourable environmental conditions. The same researchers added that in conditions of favourable environments, the most stable and adapted genotypes were 
the strains LG4 and LG5 and the cultivars M-SOY 7908 RR and M-SOY $7578 \mathrm{RR}$ since they showed lower the value of the parameter Pi.

\section{Non-Parametric Stability Components}

Nonparametric stability statistics may be based upon ranks rather than on measured Xij-values (Becker and Leon, 1988). Nonparametric stability statistics based on rank orders (of corrected $\mathrm{Xjj}$-values) have been proposed by Nassar and Huehn (1987). The results of five different non-parametric stability statistics are presented in Table 5. Nassar and Huehn's (1987) rank stability method, $\mathrm{S}_{\mathrm{i}}{ }^{(2)}$ are based on ranks of genotypes across environments and they give equal weight to each environment. Genotypes with fewer changes in ranking are considered to be more stable (Becker and Leon, 1988). Accordingly, the genotypes BATEM 306, BATEM 207 and BDSA 05 had the lowest $\mathrm{S}_{\mathrm{i}}{ }^{(2)}$ values and hence, these genotypes were accepted as the most stable genotypes. Whereas, the genotypes BDUS 04, KAMA and NOVA were considered unstable because they have the highest $S_{i}{ }^{(2)}$ values. Nassar and Huehn's (1987) two other non-parametric stability statistics $\left(\mathrm{S}_{\mathrm{i}}{ }^{(3)}\right.$ and $\left.\mathrm{S}_{\mathrm{i}}{ }^{(6)}\right)$ combine yield and stability based on yield ranks of genotypes in each environment. Considering two of these stability statistics, genotypes with the lowest values in terms of $\mathrm{S}_{\mathrm{i}}{ }^{(3)}$ and $\mathrm{S}_{\mathrm{i}}{ }^{(6)}$ could be considered stable. Consequently, the genotypes BATEM 306, BATEM 207 and BRAVO had the lowest $S_{i}{ }^{(3)}$ and $S_{i}{ }^{(6)}$ values and therefore, these genotypes were regarded as the most stable genotypes. However, the genotypes BDUS 04, BATEM 317, BATEM 223, and KAMA were not stable genotypes due to their both the highest average yields and the highest values of $S_{i}{ }^{(3)}$ and $S_{i}{ }^{(6)}$ (Table 5). Yue et al. (1997) repoted that the nonparametric parameters, $\mathrm{S}_{\mathrm{i}}{ }^{(1)}$ and $\mathrm{S}_{\mathrm{i}}{ }^{(2)}$ require no assumptions concerning normal distribution or homogeneity of variances. The same researchers stated that cultivars with higher yield and stability were determined by these two non-parametric stability parameters. Fox et al (1990) proposed a superiority parameter (TOP) method which is a non-parametric stability method obtained with the rate of the first three ranks in each environment according to performance order of genotypes tested in different environments to reveal their genotypic stability. Genotypes with a TOP value close to 100 are the most stable genotypes, and the high TOP value also indicates the general adaptability of a genotype (Fox et al., 1990). The highest TOP value was obtained from BATEM 317 genotype with 63.6, followed by BATEM 223 genotype with 54.5. The genotypes ATAEM 07, BRAVO and BATEM 207 had the lowest TOP values with 9.1. Consequently, BATEM 317 and BATEM 223 were regarded as the most stable genotypes according to the superiority parameter (TOP) of Fox et al. (1990). The last non-parametric stability statistic in the current study is Kang's (1988) rank-sum (RS) statistics. Kang (1988) noted that a genotype with a low rank-sum is regarded as the most desirable genotype. Accordingly, the genotypes BATEM 306 and BATEM 223 with the lowest rank-sum (RS) values were considered to be stable while the genotypes NOVA, ATAEM 07, KANA and KAMA having the highest ranksum (RS) values were unstable. Our findings are supported the conclusion of Yue et al. (1997), who reported that the rank-sum approach compromises the two criteria in the selection and appears to be a logical choice in selecting high and stable yield soybean cultivars.

\section{Relationship among seed yield and stability parameters}

The correlations between seed yield and stability parameters are presented in Table 6. Seed yield was positively and significantly correlated with $\mathrm{D}_{\mathrm{i}}^{2}(\mathrm{P}<0.01)$, $\mathrm{S}_{\mathrm{i}}{ }^{(6)}(\mathrm{P}<0.05)$ and TOP $(\mathrm{P}<0.01)$ and showed a negative and significant correlation with $\mathrm{P}_{\mathrm{i}}(\mathrm{P}<0.01)$ and $\mathrm{RS}(\mathrm{P}<0.01)$. The coefficient of regression (bi) had a positive significant association with $\mathrm{CVi}$, $\alpha \mathrm{i}(\mathrm{P}<0.01)$ and $\mathrm{R}_{\mathrm{i}}{ }^{2}(\mathrm{P}<0.05)$. The coefficient of determination $\left(\mathrm{R}_{\mathrm{i}}{ }^{2}\right)$ had negative and significant correlations with $\lambda_{\mathrm{i}}, \quad \mathrm{P}_{\mathrm{i}}, \quad \mathrm{RS} \quad(\mathrm{P}<0.05)$. Ecovalance $\left(\mathrm{W}_{\mathrm{i}}^{2}\right)$ was positively associated with $\mathrm{CVi}$ $(\mathrm{P}<0.01), \sigma_{\mathrm{i}}{ }^{2}(\mathrm{P}<0.01), \mathrm{P} 59(\mathrm{P}<0.01), \lambda \mathrm{i} \quad(\mathrm{P}<0.01), \mathrm{S}_{\mathrm{i}}{ }^{(2)}$ $(\mathrm{P}<0.01), \mathrm{S}_{\mathrm{i}}{ }^{(3)}(\mathrm{P}<0.01), \mathrm{S}_{\mathrm{i}}{ }^{(6)}(\mathrm{P}<0.01)$ and $\mathrm{RS}(\mathrm{P}<0.05)$. Stability variance $\left(\sigma_{i}^{2}\right)$ had positive and significant correlations with $\mathrm{P} 59, \lambda \mathrm{i}, \mathrm{S}_{\mathrm{i}}{ }^{(2)}(\mathrm{P}<0.01), \mathrm{S}_{\mathrm{i}}{ }^{(3)}(\mathrm{P}<0.01), \mathrm{S}_{\mathrm{i}}{ }^{(6)}$ $(\mathrm{P}<0.01)$, and $\mathrm{RS}(\mathrm{P}<0.05)$. $\mathrm{P} 59$ was positively and significantly correlated with $\lambda \mathrm{i}(\mathrm{P}<0.01), \mathrm{S}_{\mathrm{i}}^{(2)}(\mathrm{P}<0.01), \mathrm{S}_{\mathrm{i}}{ }^{(3)}$ $(\mathrm{P}<0.01), \mathrm{S}_{\mathrm{i}}{ }^{(3)} \quad(\mathrm{P}<0.01)$ and $\mathrm{RS}(\mathrm{P}<0.05)$. Desirability index $\left(D_{i}\right)$ had negatively significant correlations with $P_{i}$ and RS $(\mathrm{P}<0.01)$ while a positive correlation with TOP $(\mathrm{P}<0.01)$. Alpha $(\alpha \mathrm{i})$ was only positively and significantly associated with $\mathrm{S}_{\mathrm{i}}{ }^{(6)}(\mathrm{P}<0.05)$. Lamda $(\lambda \mathrm{i})$ had positive and significant correlations with $\mathrm{S}_{\mathrm{i}}^{(2)}(\mathrm{P}<0.01), \mathrm{S}_{\mathrm{i}}^{(3)}(\mathrm{P}<0.01)$, $\mathrm{S}_{\mathrm{i}}{ }^{(6)}(\mathrm{P}<0.05)$ and $\mathrm{RS}(\mathrm{P}<0.01)$. The superiority index $\left(\mathrm{P}_{\mathrm{i}}\right)$ was negatively correlated with TOP $(\mathrm{P}<0.01)$ and positively associated with $\mathrm{RS}(\mathrm{P}<0.01)$. A non-parametric stability method, $\mathrm{S}_{\mathrm{i}}{ }^{(2)}$ was significantly correlated with $\mathrm{S}_{\mathrm{i}}{ }^{(3)}$ and $\mathrm{S}_{\mathrm{i}}{ }^{(6)}(\mathrm{P}<0.01)$. One other non-parametric method, $\mathrm{S}_{\mathrm{i}}{ }^{(3)}$ had positive and significant correlations with $\mathrm{S}_{\mathrm{i}}{ }^{(6)}(\mathrm{P}<0.01)$ and TOP $(\mathrm{P}<0.05) . \mathrm{S}_{\mathrm{i}}{ }^{(6)}$ parameter showed only a positive association with TOP $(\mathrm{P}<0.01)$. 
Table 6. Relationships between seed yields, parametric and non-parametric stability parameters for 14 soybean genotypes across 11 environments

\begin{tabular}{|c|c|c|c|c|c|c|c|c|c|c|c|c|c|c|c|}
\hline Measure & $\mathrm{X}$ & bi & $\mathrm{Ri}^{2}$ & $\mathrm{Wi}^{2}$ & $\mathrm{CV}_{\mathrm{i}}$ & $\sigma_{i}^{2}$ & P59 & $\mathrm{Di}_{\mathrm{i}}^{2}$ & $\alpha_{\mathrm{i}}$ & $\lambda_{\mathrm{i}}$ & $\mathrm{P}_{\mathrm{i}}$ & $\mathrm{Si}^{(2)}$ & $\mathrm{Si}^{(3)}$ & $\mathrm{Si}^{(6)}$ & TOP \\
\hline bi & 0.328 & & & & & & & & & & & & & & \\
\hline $\mathrm{Ri}^{2}$ & 0.477 & $0.564^{*}$ & & & & & & & & & & & & & \\
\hline $\mathrm{Wi}^{2}$ & -0.055 & 0.343 & -0.476 & & & & & & & & & & & & \\
\hline $\mathrm{CV}_{\mathrm{i}}$ & 0.082 & $0.881 * *$ & 0.161 & $0.689 * *$ & & & & & & & & & & & \\
\hline$\sigma_{\mathrm{i}}^{2}$ & -0.055 & 0.343 & -0.476 & $1.000 * *$ & $0.689 * *$ & & & & & & & & & & \\
\hline P59 & -0.055 & 0.343 & -0.476 & $1.000^{* *}$ & $0.689 * *$ & $1.000^{* *}$ & & & & & & & & & \\
\hline $\mathrm{Di}_{\mathrm{i}}^{2}$ & $0.981 * *$ & 0.142 & 0.393 & -0.138 & -0.100 & -0.138 & -0.139 & & & & & & & & \\
\hline ai & 0.308 & $0.978 * *$ & 0.490 & 0.445 & $0.933 * *$ & 0.445 & 0.446 & 0.120 & & & & & & & \\
\hline$\lambda_{\mathrm{i}}$ & -0.107 & 0.208 & $-0.593^{*}$ & $0.940 * *$ & $0.589 *$ & $0.940 * *$ & $0.941 * *$ & -0.164 & 0.304 & & & & & & \\
\hline$P_{i}$ & $-0.950 * *$ & -0.301 & $-0.655^{*}$ & 0.315 & 0.045 & 0.315 & 0.314 & $-0.940 * *$ & -0.249 & 0.358 & & & & & \\
\hline $\mathrm{Si}^{(2)}$ & -0.025 & 0.389 & -0.416 & $0.959^{* *}$ & $0.728 * *$ & $0.959^{* *}$ & $0.960 * *$ & -0.117 & 0.502 & $0.913 * *$ & 0.274 & & & & \\
\hline $\mathrm{Si}^{(3)}$ & 0.437 & 0.431 & -0.236 & $0.808 * *$ & $0.634 *$ & $0.808^{* *}$ & $0.807 * *$ & 0.358 & 0.524 & $0.763 * *$ & -0.196 & $0.842 * *$ & & & \\
\hline $\mathrm{Si}^{(6)}$ & $0.601 *$ & 0.469 & -0.065 & $0.688 * *$ & $0.597 *$ & $0.689 * *$ & $0.688 * *$ & 0.523 & $0.560 *$ & $0.625 *$ & -0.387 & $0.729 * *$ & $0.972 * *$ & & \\
\hline TOP & $0.743 * *$ & 0.365 & 0.214 & 0.197 & 0.323 & 0.197 & 0.197 & $0.688^{* *}$ & 0.416 & 0.189 & $-0.618 *$ & 0.221 & $0.648 *$ & $0.760 * *$ & \\
\hline RS & $-0.736 * *$ & 0.043 & $-0.639 *$ & $0.559 *$ & 0.373 & $0.559 *$ & $0.559 *$ & $-0.784 * *$ & 0.075 & $0.545^{*}$ & $0.853 * *$ & 0.519 & 0.150 & -0.046 & -0.391 \\
\hline
\end{tabular}

for pair-wise GEI, $\mathrm{Di}^{2}$ : desirability index, $\alpha_{i}$ : environmental effects, $\lambda_{i}$ : deviation from the linear response, $\mathrm{Pi}$ : superiority index, $\mathrm{Si}^{(2)}, \mathrm{Si}^{\left({ }^{(2)}\right.}, \mathrm{Si}^{(6)}$ : nonparametric $\mathrm{stability}^{(2 t a t i s t i c s,}$

TOP: superiority parameter, RS: rank-sum 
When the results of correlation analysis were evaluated, it was seen that between seed yield and many stability parameters were also significant relations as well as to be between each of these parameters. Especially, the strong linear correlations between regression coefficient (bi) and $\mathrm{CVi}, \alpha \mathrm{i}$ and $\mathrm{R}_{\mathrm{i}}{ }^{2}$ parameters shows that these parameters give parallel results to each other (Table 6). According to Oliveira et al. (2003), the correlation between the estimates of parameters of adaptability and/or stability contributes to better predict the behavior of the evaluated genotypes. Oleivera et al. (2012) reported that comparing the four methods used in their study, there was an agreement with the classification of the strain LG 4 for greater adaptability and stability in a favourable environment. Morsy et al. (2012) found high positive correlation coefficient (0.97**) between mean seed yield and YS (yield stability) indicating that using YS as a stability parameter may not provide more information than the mean seed yield itself. Yue et al. (1997) found that the regression coefficient was correlated significantly with the coefficient of variation but showed virtually no correlation with other stability measures. Also, they revealed that the paired correlation coefficients between $\mathrm{W}_{\mathrm{i}}, \mathrm{S}_{\mathrm{di}}{ }^{2} \mathrm{~S}_{\mathrm{i}}{ }^{(1)}$, and $\mathrm{S}_{\mathrm{i}}^{(2)}$ were all highly significant, indicating their close relationship with each other. According to the correlation matrix, parametric and nonparametric stability methods used in this study revealed that these parameters could be used for evaluating the responses of soybean genotypes to changing environments.

\section{CONCLUSION}

This study has provided the evaluation of the environmental and agronomic performance of certain soybean genotypes. For this, adaptation-stability cases of genotypes were examined comparatively using different 12 parametric and 5 non - parametric stability analysis methods. The genotypes, environments and GEI played a significant role in terms of seed yield in this study. According to most parametric and non-parametric stability methods, BATEM 223, BATEM 306, BATEM 317 and KASM 02 were determined to be stable genotypes. These genotypes demonstrated superior adaptability with high yield performances in many environments. According to Eberhart and Russell (1966), genotypes BDSA 05, BDUS 04 and KAMA had higher seed yields and regression coefficient values above 1.0. These genotypes are sensitive to environmental variations and would be suggested for cultivation under favourable conditions, while BATEM 207 with bi<1 and medium level seed yield were moderately adapted across unfavourable environmental conditions. Results of correlation analysis indicated that seed yield was positively and significantly correlated with $\mathrm{D}_{\mathrm{i}}{ }^{2}(\mathrm{P}<0.01), \mathrm{S}_{\mathrm{i}}{ }^{(6)}(\mathrm{P}<0.05)$ and TOP $(\mathrm{P}<0.01)$ and showed a negative and significant correlation with $\mathrm{P}_{\mathrm{i}}(\mathrm{P}<0.01)$ and RS ( $\mathrm{P}<0.01)$. In addition, the coefficient of regression (bi) had a positive significant association with $\mathrm{CVi}, \alpha \mathrm{i}(\mathrm{P}<0.01)$ and $\mathrm{R}_{\mathrm{i}}^{2}(\mathrm{P}<0.05)$.

\section{ACKNOWLEDGMENTS}

This research was funded by the Scientific and Technological Research Council of Turkey (TUBITAK, project number 1130082). The authors thank TUBITAK for their financial support.

\section{LITERATURE CITED}

Al-Assily, Kh.A. S.M. Nasr, Kh. A. Ali. 1996. Genotype $\times$ environment interaction, yield stability and adaptability for soybean (Glycine max L.). J. Agric. Sci. Mansoura Univ. 21: 3779-3789.

Arioglu, H., S. Ozyurtseven, L. Gulluoglu. 2012. The determination of crude oil yield and fatty acids composition of some soybean [Glycine max (L.) Merr] varieties in double cropped conditions-II. Journal of Cukurova University Faculty of Agriculture 27(2):1-10 (In Turkish).

Becker, H.C. and J. Leon. 1988. Stability analysis in plant breeding. Plant Breed. 101: 1-23.

Carvalho, C.G.P., C.A.A. Arias, J.F.F. Toledo, L.A. Almeida, R.A. Kiihl, M.F. Oliveira. 2002. Adaptability and stability study of soybean lines developed for high yield in Paraná State using four methodologies. Crop Breeding and Applied Biotechnology 2(2): 247-256.

Chaudhary, K.R. and J. Wu. 2012. Stability analysis for yield and seed quality of soybean [Glycine max (L.) Merril] across different environments in eastern South Dakota. Conference on Applied Statistics in Agriculture, Kansas State University.

Cheelo, P., D. Lungu, M. Mwala. 2017. GGE biplot analysis for identification of ideal soybean [Glycine max L. Merrill] test and production locations in Zambia. Journal of Experimental Agriculture International 15(3): 1-15.

Cruz, C.D. 2006. Programa Genes - Estatística Experimental e Matrizes. Viçosa, MG: UFV.

Cruz, C.D., P.C.S. Carneiro. 2006. Modelos biométricos aplicados ao melhoramento genético. Viçosa: UFV, 2: 585p

Cruz C.D., A.J. Regazzi, P.C.S. Carneiro. 2012. Biometric models applied to genetic improvement. Viçosa, MG: UFV, 1: 514.

Cucolotto, M., V.C. Pipolo, D.D. Garbuglio, N.S.F. Junior, D. Destro, M.K. Kamikoga. 2007. Genotype x environment interaction in soybean: evaluation through three methodologies. Crop Breeding and Applied Biotechnology 7: 270-277.

Eberhart, S.A., W.A. Russelli. 1966. Stability parameters for comparing varieties. Crop Sci. 6: 36-40.

Edugbo, R.E., G.E. Nwofia, L.S. Fayeun. 2015. An assessment of soybean (Glycine max L. Merrill) grain yield in different environments using AMMI and GGE biplot models in humidorest fringes of southeast Nigeria. Agricultura Tropica et Subtropica 48(3-4): 82-90.

EL-Refaey, R.A., E.H. EL-Seidy, M.A. El-Borai, T.M. Abu Sein. 2013. Phenotypic stability parameters of yield for some soybean genotypes. Egypt Journal of Plant Breed. 17(2): 455466.

Fox, P.N., B. Skovmand, B.K. Thompson, H.J. Braun, R. Cormier. 1990. Yield and adaptation of hexaploid spring triticale. Euphytica 47: 57-64.

Francis, T.R., L.W. Kannenberg. 1978. Yield stability studies in short-season maize. I. A descriptive method for grouping genotypes. Can J. Plant Sci. 58: 1029-1034.

Freiria, G.H., L.S.A. Goncalves, F.F. Furlan, N.S.F. Junior, W.F. Lima, C.E.C. Prete. 2018. Statistical methods to study adaptability and stability in breeding lines of food-type soybeans. Bragantia 77(2): 253-264. 
Gurmu, F., H. Mohammed, G. Alemaw. 2009. Genotype and environment interaction and stability of soybean for grain yield and nutritional quality. Afr. Crop Sci. J. 17: 87-99.

Hernandez, C.M., J. Crossa, A. Castillo. 1993. The area under the function: An index for selecting desirable genotypes. Theor. Appl. Genet. 87: 409-415.

Hossain, M.A., L. Rahman, A.K.M. Shamsuddin. 2003. Genotype and environment interaction and stability analysis in soybean. J. Biol. Sci., 3: 1026-1031.

Huehn, M. 1979. Beitrage zur erfassung der phanotypischen stabilitat. EDV Med. Biol., 10: 112-117.

Ilker, E., M. Kocaturk, A. Kadiroglu, M. Altinbas, A. Yildirim, G. Ozturk, H. Yildiz. 2018. Stability analyses for double cropping in soybean [Glycine $\max$ (L.) Merrill]. Turkish Journal of Field Crops 23(2): 80-84.

Kahraman, S., U. Sevilmis, H. Karahan. 2019. Investigation of second crop no-tilled soybean crop performance in kiziltepe conditions of Turkey. International Journal of Eastern Mediterranean Agricultural Research 2(1): 13-19.

Kang, M.S., J.D. Miller, L.L. Darrah. 1987. A note on relationship between stability variance and ecovalence. J. Hered. 78: 107

Kang, M.S. 1988. A rank-sum method for selecting high yielding, stable corn genotypes. Cereal Research Communications 16: 113-115.

Lin, C.S., M.R. Binns, L.P. Lefkovitch. 1986. Stability analysis: Where do we stand? Crop Sci. 26: 894-900.

Lin, C.S., M.R. Binns. 1988. A method of analysing cultivar $\times$ location $\times$ year experiments: A new stability parameter. Theor. Appl. Genet. 76: 425-430.

Morsy, A.R., W.M. Fares, A.M. El-Garhy, A.A.M. Ashrie. 2012. Evaluation of regression models and variance measures as stability parameters of some soybean genotypes. Alex. J. Agric. Res. 57(2): 141-152.

Morsy, A.R., W.M. Fares, S.B. Ragheb, M.A. Ibrahim. 2015. Stability analysis of some soybean genotypes using a simplified statistical model. J. Plant Production, Mansoura Univ. 6 (12): 1975 - 1990.

Nassar, R., M. Huehn. 1987. Studies on estimation of phenotypic stability: tests of significance for non-parametric measures of phenotypic stability. Biometrics 43: 45-53.

Oliveira, A.B., J.B. Duarte, J.B. Pinheiro. 2003. Emprego da análise AMMI na avaliação da estabilidade produtiva em soja. Pesqui. Agropecu. Bras. 38: 357-364

Oliveira, L.G., O.T. Hamawaki, G.A. Simon, L.B. Sousa, A.P.O. Nogueira, D.F. Rezende, C.D.L. Hamawaki. 2012. Adaptability and stability of soybean yield in two soybean producing regions. Biosci. J., Uberlândia 28(6): 852-861.

SAS Institute. 1999. SAS/STAT user's guide. 8. Version. SAS Institute Inc. Cary. NC.
Pinthus, M.J. 1973. Estimates of genotypic value: a proposed method. Euphytica 22: 345-351.

Plaisted, R.L., L.C.A. Peterson. 1959. Technique for evaluating the ability of selections and yield consistency in different locations or seasons. Am. Potato J. 36: 381-385.

Primomo, V.S., D.E. Falk, G.R. Ablett, J.W. Taner, I. Rajcan. 2002. Genotype $x$ environment interactions, stability, and agronomic performance of soybean with altered fatty acid profiles. Crop Sci. 42: 37-44.

Ramalho, M.A.P., D.F. Ferreira, A.C. de. Oliveira. 2012. Experimentação em genética e melhoramento de plantas. Lavras: Ufla 305p.

Sousa, J.L.M., M. de M. Rocha, K.J.D. Silva, A.C. das Neves, R.R. de. Sousa. 2015. Potencial de genótipos de feijão-caupi para o mercado de vagens e grãos verdes. Pesquisa Agropecuária Brasileira 50: 392-398.

Shukla, G.K. 1972. Some statistical aspects of partitioning genotype-environmental components of variability. Heredity 29: 237-245.

Silveira, D.A., L.F. Pricinotto, M. Nardino, C.A. Bahry, C.E.C. Prete, L. Cruz. 2016. Determination of the adaptability and stability of soybean cultivars in different locations and at different sowing times in Paraná state using the AMMI and Eberhart and Russel methods. Semina 37: 3973-3982.

Steel, R.G.D., J.H. Torrie. 1980. Principles and Procedures of Statistics. A biometrical approach. 2nd edition. McGraw-Hill, New York, USA, pp. 20-90.

Tadesse, M., A. Elmi, T. Mebrahtu, E. Abdulkadir. 1997. Stability analysis of vegetable soybean. Soybean Genetics Newsletter 24: $214-216$.

Tai, G.C.C. 1971. Genotypic stability analysis and its application to potato regional trials. Crop Sci. 11: 184-190.

Wricke, G. 1962. On a method of understanding the biological diversity in field research. Z. Pflanzenzucht, 47: 92-46.

Wricke, G., W.E. Weber. 1980. Erweiterte Analyse von Wechselwirkungen in Versuchsserien. In: W. Kopcke and K. Uberla (Eds), Biometrie-heute und morgen. Springer Verlag 094 Berlin-Heidelberg-New York, pp. 87-95.

Yılmaz, H., P. Cubukcu, M. Gul, A.K. Sahar, M.G. Akpınar. 2019. Development in soybean production and foreign trade in Turkey. International Journal of Agriculture, Forestry and Life Science 3(1): 84-88.

Yothasiri, A., T. Somwang, Y. Amnuay, S. Teera. 2000. Stability of soybean genotypes in Central Plain Thailand. Kasetsart J. Nat. Sci. 34: 315-322.

Yue, G.L., K.L. Roozeboom, W.T. Schapaugh, G.H. Liang. 1997. Evaluation of soybean cultivars using parametric and nonparametric stability estimates. Plant Breeding 116: 271275. 